НАУКОВИЙ ВІСНИК

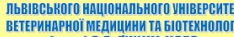
імені в.3. гницыного Scientific messenger of L L wiv National University of
Veterinary Medicine and Biotechnologies

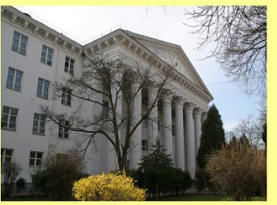

СЕРІЯ "ЕКОНОМІчН НАУКІ

Том 23 № 98 2021

Науковий вісник Дьвівського національного університету ветеринарної медицини та біотехнологій імені С.3. Гжицького. Серія: Економічні науки

\author{
Scientific Messenger of Lviv National University \\ of Veterinary Medicine and Biotechnologies. \\ Series: Economical Sciences
}

UDC 351.37

\title{
Approaches to the analysis of enterprise's financial state on the example of Cargill Animal Nutrition LLC
}

B. B. Brychka

Stepan Gzhytskyi National University of Veterinary Medicine and Biotechnologies Lviv, Lviv, Ukraine

\section{Article info}

Received 10.10.2020

Received in revised form

29.11.2020

Accepted 01.12.2020

Stepan Gzhytskyi National University of Veterinary Medicine and Biotechnologies Lviv, Pekarska Str., 50, Lviv, 79010, Ukraine.

Tel: $+038-097-279-59-18$

E-mail:

brychkaBh@gmail.com
Brychka, B. B. (2021). Approaches to the analysis of enterprise's financial state on the example of Cargill Animal Nutrition LLC. Scientific Messenger of Lviv National University of Veterinary Medicine and Biotechnologies. Series: Economical Sciences, 23(98), 12-16. doi: 10.32718/nvlvete9802

The article analyzes the financial statements of Cargill Animal Nutrition LLC, which aims to become a leader in feed production. The urgency of the need to find optimal ways to assess the financial state of enterprises to take the necessary measures in case of instability of the firm is substantiated. The main methods of analysis of financial statements of companies have been identified and substantiated, which will allow agricultural enterprises to analyze their financial state and take measures to optimize their activities. Various approaches have been applied to the analysis of the company's financial position, including horizontal analysis of balance sheet indicators and statement of financial performance, vertical analysis of the balance sheet structure, and coefficient analysis of profitability, liquidity and solvency of the company, with a comprehensive assessment of bankruptcy. Vertical analysis is used to track the structure of a company's assets and liabilities over a period. This analysis makes it possible to draw conclusions about the liquidity and solvency of the company. Horizontal analysis helps to analyze the growth rates of various indicators presented in the financial statements. Finally, the ratio analysis is a system of ratios that allows you to analyze the liquidity, profitability, solvency and investment attractiveness of the company compared to other companies. According to the results of the study, it was concluded that the financial state of Cargill EN LLC has improved. In particular, the net profit margin of Cargill EN LLC improved from $3.1 \%$ in 2018 to $10 \%$ in 2020. According to the value of Altman's Z-score, the probability of bankruptcy is very low. Perspective directions of researches in a part of an estimation of the generalized indicator of instability of the company taking into account features of an agro-industrial complex of Ukraine are substantiated.

Key words: financial analysis, profitability, liquidity, solvency, production.

\section{Підходи до аналізу фінансового стану підприсмства на прикладі ТОВ “Каргілл Енімал Нутрішн”}

\author{
Б. Б. Бричка
}

Львівський національний університет ветеринарної медицини та біотехнологій імені С. 3. Гљицького, м. Львів, Україна

У статті проведено аналіз фінансової звітності ТОВ “Каргілл Енімал Нутрішн”, яка прагне стати лідером у виробництві кормів. Обтрунтовано актуальність необхідності пошуку оптимальних шляхів оцінки фінансового стану підприємств для вжиття необхідни заходів у випадку нестабільності стану фірми. Визначено та обтрунтовано основні способи аналізу фінансової звітності компаній, щуо дасть змогу агропідприємствам проводити аналіз свого фінансового стану та приймати заходи для оптимізаціі своєї діяльності. Застосовано різні підходи до аналізу фінансового стану підприємства, включаючи горизонтальний аналіз динаміки індикаторів балансу та звіту про фінансові результати, вертикальний аналіз структури балансу, а також коефіцієнтний аналіз рентабельності, ліквідності та платоспроможності компанї, з прикладом комплексної оцінки ймовірності банкрутства. Вертикальний аналіз використовується для простежування структури активів та пасивів компанії протягом певного періоду 
часу. Такий аналіз дає можливість зробити висновок щьоо ліквідності та платоспроможності компаніі. Горизонтальний аналіз допомагає проаналізувати темпи зростання різних показників, представлених у фінансовій звітності. Нарешті, аналіз коефіцієнтів - це система коефіцієнтів, щзо дає можливість аналізувати ліквідність, прибутковість, платоспроможність та інвестиційну привабливість компанії порівняно з іншими компаніями. За результатами дослідження зроблено висновок про покращення фінансового стану компанії ТОВ “Каргілл ЕН”. Зокрема, рентабельність продажу ТОВ “Каргілл ЕН” покращилась з 3,1 \% у 2018 році до $10 \%$ у 2020 рочі. Відповідно до значення показника Z-рахунку Альтмана, ймовірність банкрутства фірми є дуже низькою. Обтрунтовано перспективні напрями досліджень в частині очінки узагальненого показника нестабільності компанії з врахуванням особливостей агропромислового комплексу України.

Ключові слова: фінансовий аналіз, рентабельність, ліквідність, платоспроможність, виробництво.

\section{Вступ}

Забезпечення сталого розвитку підприємств $\epsilon$ пріоритетом та передумовою стійкого економічного зростання та забезпечення зростання життєвого рівня населення. Водночас, в умовах глобалізації ринків та підвищення конкурентного середовища актуалізується необхідність пошуку оптимальних шляхів оцінки фінансового стану підприємств для вжиття необхідних заходів у випадку нестабільності ситуації. При цьому, недостатня фінансова стабільність підприємств в межах вітчизняного господарства доповнюється недостатньою дієвістю основних інструментів макроекономічного регулювання, що знижує прогнозованість розвитку економічних орієнтирів та стримує досягнення фінансової стабільності підприємств. У цьому контексті зростає необхідність підвищення ефективності оцінки та аналізу фінансового стану підприємств у напрямі напрацювання і впровадження нових концептуальних підходів до вирішення існуючих проблем.

Підходи до аналізу фінансової звітності підприємства та пошук найбільш ефективних шляхів підвищення стійкості його фінансового стану досліджені у працях таких науковців як Базілінська О. Я. (Bazilinska, 2009), Бреус С. В. (Breus \& Shmatukha, 2016). Зайцев О. В. (Valiukh \& Zaitsev, 2019). Краснікова О. М., Мiхалець А. I. (Krasnikova \& Mikhalets, 2020), Сосновська О. О. (Sosnovska, 2019), Ткачук Г. О. Рибалко С. В., Скляр Л. Б. (Tkachuk et al., 2020) та інші.

Мета $і$ завдання дослідження полягає у визначенні та обгрунтуванні основних способів аналізу фінансової звітності компаній, що дасть змогу агропідприємствам проводити аналіз свого фінансового стану та приймати заходи для оптимізації діяльності. Для досягнення поставленої мети потрібно застосувати різні підходи до аналізу фінансового стану підприємства, включаючи горизонтальний аналіз динаміки індикаторів балансу та звіту про фінансові результати, вертикальний аналіз структури балансу, а також коефіцієнтний аналіз рентабельності, ліквідності та платоспроможності компанії, 3 прикладом комплексної оцінки ймовірності банкрутства.

\section{Матеріал і методи досліджень}

В основу дослідження покладено сучасні положення теорії фінансів, фінансового менеджменту, фінансового аналізу. У роботі застосовано сукупність методів наукового пізнання, зокрема: індукції і дедукції, аналізу і синтезу - для аналізу обчислених коефіцієнтів та синтезу наявної інформації для вироблення висновків, групування та систематизації - при групуванні фінансової інформації; фінансового аналізу - для вивчення тенденцій зміни окремих показників рентабельності, ліквідності, платоспроможності та оборотності.

\section{Результати та їх обговорення}

Основною метою аналізу фінансової звітності підприємства є прийняття висновків про фінансову стійкість, рентабельність та інвестиційну привабливість фірми. Як вірно зазначає Сосновська О.: “Всі суб'єкти, які мають відношення до ділового життя підприємства та бізнесу, повинні використовувати методику фінансового аналізу для прийняття рішень, спрямованих на оптимізацію своїх інтересів" (Sosnovska, 2019). На думку Краснікової О.М., виявлення та усунення недоліків у фінансовій діяльності компанії та пошук резервів покращення іiі фінансового стану $є$ основною метою фінансового аналізу (Krasnikova \& Mikhalets, 2020).

ТОВ “Каргілл Енімал Нутрішн” - провідна фірма 3 виробництва готових кормів для тварин, що утримуються на фермах у Західному регіоні України. Компанія $є$ сучасним комбікормовим заводом, побудованим у 2007 році. Завод розташований у с. Жорниська, Яворівського району Львівської області.

Економісти застосовують багато інструментів для аналізу фінансової звітності компаній, включаючи інструменти вертикального та горизонтального аналізу, аналізу коефіцієнтів тощо. Вертикальний аналіз використовується для простежування структури активів та пасивів компанії впродовж певного періоду часу. Такий аналіз дає можливість прийняти рішення щодо ліквідності та платоспроможності компанії. Наприклад, якщо частка оборотних активів збільшується в структурі загальних активів компанії, ії ліквідність зростає. У свою чергу, якщо відсоток зобов'язань зростає, платоспроможність компанії падає. Горизонтальний аналіз допомагає проаналізувати темпи зростання різних індикаторів, представлених у фінансовій звітності. Нарешті, аналіз коефіцієнтів - це система коефіцієнтів, що дає можливість аналізувати ліквідність, прибутковість, платоспроможність та інвестиційну привабливість компанії порівняно з іншими компаніями.

Відповідно до річного звіту ТОВ “Каргілл Енімал Нутрішн”, загальний обсяг продажів фірми збільшився з 635 млн. грн. у 2018 р. до 842 млн. грн. за підсумками 2020 р. Чистий прибуток компанії також продемонстрував позитивну динаміку росту з 20,2 млн. грн. у 2018 році до 84 млн. грн. у 2020 році.

Аналізуючи баланс ТОВ “Каргілл ЕН”, помічаємо, що частка грошових коштів в структурі активів компа- 
нії знизилася з 2,48 \% у 2018 році до $0,04 \%$ та $0,78 \%$ у 2019 та 2020 рр. відповідно. Це може свідчити про низьке значення миттєвої ліквідності компанії. Як ві-

домо, коли частка грошових коштів зменшується у структурі загальних активів, ліквідність підприємства погіршується.

\section{Таблиця 1}

Аналіз структури активів та пасивів ТОВ “Каргілл ЕН”

\begin{tabular}{|c|c|c|c|}
\hline Вертикальний аналіз & 2018 p. & 2019 p. & 2020 p. \\
\hline Грошові кошти та їх еквіваленти & $2,48 \%$ & $0,04 \%$ & $0,78 \%$ \\
\hline Дебіторська заборгованість & $42,97 \%$ & $48,53 \%$ & $48,37 \%$ \\
\hline Запаси & $65,64 \%$ & $55,84 \%$ & $65,47 \%$ \\
\hline Оборотні активи & $78,58 \%$ & $76,52 \%$ & $81,93 \%$ \\
\hline Баланс & $100,00 \%$ & $100,00 \%$ & $100,00 \%$ \\
\hline Кредиторська заборгованість & $52,27 \%$ & $30,83 \%$ & $33,61 \%$ \\
\hline Поточні зобов'язання разом & $83,96 \%$ & $62,41 \%$ & $58,98 \%$ \\
\hline Зобов'язання & $83,96 \%$ & $62,41 \%$ & $58,98 \%$ \\
\hline Власний капітал & $16,04 \%$ & $37,59 \%$ & $41,02 \%$ \\
\hline
\end{tabular}

Джсерело: розраховано автором за матеріалами офіційних даних звітності ТОВ “Каргілл Енімал Нутрішн” (Finansova zvitnist "TOV "KARHILL EN", 2021)

3 результатів аналізу структури активів та пасивів компанії видно, що частка дебіторської заборгованості $€$ достатньо значною, досягаючи майже 50 \% усіх активів фірми. При цьому, компанії важливо утримувати частку сумнівної та безнадійної заборгованості на низькому рівні. Крім цього, частка зобов'язань компанії знизилась з 83,9 \% у 2018 році до $59 \%$ у 2020 році, але вона все ще залишається дуже значною. Рентабельність $\epsilon$ один з основних показників успіху діяльності компа- нії. Коефіцієнти рентабельності дають можливість порівняти ефективність діяльності компаній з різних галузей промисловості. Рентабельність активів показує частку чистого прибутку, що генерується кожною гривнею загальних активів фірми. Що вища рентабельність активів компанії, то ефективніше вони використовуються. Рентабельність активів ТОВ “Каргілл ЕН" підвищилась 3 5,9 \% у 2018 році до 16,5 \% у 2020 році.

\section{Таблиця 2}

Показники рентабельності ТОВ “Каргілл ЕН”

\begin{tabular}{lccc}
\hline \multicolumn{1}{c}{ Показники рентабельності } & $2018 \mathrm{p}$. & $2019 \mathrm{p}$. & $2020 \mathrm{p}$. \\
\hline Рентабельність активів & $5,95 \%$ & $21,22 \%$ & $16,49 \%$ \\
Рентабельність довгострокового капіталу & $45,93 \%$ & $68,96 \%$ & $49,43 \%$ \\
Рентабельність власного капіталу & $37,08 \%$ & $56,44 \%$ & $40,20 \%$ \\
Рентабельність продажу & $3,18 \%$ & $10,08 \%$ & $9,99 \%$ \\
Валова маржа & $23,90 \%$ & $29,63 \%$ & $30,65 \%$ \\
Операційна маржа & $8,24 \%$ & $15,99 \%$ & $13,56 \%$ \\
\hline
\end{tabular}

Джерело: розраховано автором за матеріалами офіційних даних звітності ТОВ “Каргілл Енімал Нутрішн” (Finansova zvitnist "TOV “KARHILL EN", 2021)

Як відомо, власники компанії прагнуть повернення своїх інвестицій, а тому рентабельність власного капіталу є дуже важливим коефіцієнтом прибутковості. Він показує, скільки чистого прибутку приносить компанії кожна гривня власного капіталу. Як бачимо 3 даних наведених у таблиці 2, рентабельність власного капіталу ТОВ “Каргілл ЕН” зросла з 37 \% у 2018 році до
54,4 \% у 2019 році, але знизилася до 40,2 \% у 2020 році. Важливо відзначити, що рентабельність продажу компанії також покращилась з 3,1 \% у 2018 році до 10 \% у 2020 році. Однак, незважаючи на зростання усіх показників рентабельності у 2020 році порівняно 32018 роком, значення практично усіх коефіцієнтів знизились порівняно з 2019 роком.

\section{Таблиця 3}

Показники ліквідності ТОВ “Каргілл ЕН”

\begin{tabular}{lccc}
\hline \multicolumn{1}{c}{ Показники ліквідності } & 2018 p. & 2019 p. & 2020 p. \\
\hline Коефіцієнт загальної ліквідності & 0,94 & 1,23 & 1,39 \\
Коефіцієнт швидкої ліквідності & 0,15 & 0,33 & 0,28 \\
Коефіцієнт миттєвої ліквідності & 0,03 & 0,00 & 0,01 \\
Чистий оборотний капітал & $-18273,00$ & 46957,00 & 117032,00 \\
\hline
\end{tabular}

Джерело: розраховано автором за матеріалами офіційних даних звітності ТОВ “Каргілл Енімал Нутрішн” (Finansova zvitnist "TOV "KARHILL EN", 2021)

Ліквідність означає здатність компанії покривати поточні зобов'язання за допомогою оборотних активів.
Зокрема, коефіцієнт загальної ліквідності обчислюється шляхом відношення оборотних активів компанії до 
іiї поточних зобов’язань. Коефіцієнт загальної ліквідності ТОВ “Каргілл ЕН” збільшився з 0,94 у 2018 році до 1,39 у 2020 році. Таке значення коефіцієнта $є$ прийнятним, оскільки поточні активи компанії повністю покривають іiї поточні зобов'язання, що свідчить про високу загальну ліквідність фірми. Нормативне значення коефіцієнта загальної ліквідності знаходиться в межах від 1 до 2. Зростання чистого оборотного капіталу компанії з -18,2 млн. грн. у 2018 році до 117 млн. грн. у 2020 році також підтверджує висновок щодо покращення загальної ліквідності компанії.
Коефіцієнт швидкої ліквідності продемонстрував подібну динаміку, збільшившись з 0,15 у 2018 році до 0,28 у 2020 році. Однак, значення коефіцієнта швидкої ліквідності ТОВ “Каргілл ЕН” є неприйнятним, оскільки воно не відповідає нормативному значенню $0,7-0,8$. Варто підкреслити, що значення коефіцієнта миттєвої ліквідності було надзвичайно малим впродовж аналізованого періоду, а тому компанії слід вжити заходів для підвищення іiї швидкої та миттєвої ліквідності. Показники оборотності часто застосовуються для вимірювання ефективності використання активів компанії.

\section{Таблиця 4}

Показники оборотності ТОВ “Каргілл ЕН”

\begin{tabular}{lccc}
\hline \multicolumn{1}{c}{ Показники оборотності } & 2018 p. & 2019 p. & 2020 p. \\
\hline Коефіцієнт оборотності запасів & 2,85 & 3,77 & 2,52 \\
Коефіцієнт оборотності дебіторської заборгованості & 4,36 & 4,34 & 3,41 \\
Середній період погашення дебіторської заборгованості (у днях) & 83,80 & 84,17 & 106,91 \\
Середній період погашення кредиторської заборгованості (у днях) & 101,95 & 53,48 & 74,30 \\
Середній період конвертованості грошових коштів та їх еквівалентів (у днях) & 4,84 & 0,06 & 1,72 \\
\hline
\end{tabular}

Джерело: розраховано автором за матеріалами офіційних даних звітності ТOB “Каргілл Енімал Нутрішн” (Finansova zvitnist "TOV "KARHILL EN", 2021)

Коефіцієнт оборотності запасів обчислюється як відношення собівартості реалізованої продукції до запасів, вимірюючи кількість оборотів запасів компанії протягом операційного циклу. Чим більша кількість оборотів запасів компанії, тим вища ефективність їх використання. Коефіцієнт оборотності запасів ТОВ “Каргілл ЕН" знизився 3 2,8 у 2018 році до 2,5 у 2020 році, що свідчить про погіршення ефективності використання запасів фірми. Коефіцієнт оборотності дебіторської заборгованості також показав негативну динаміку, знизившись з 4,3 у 2018 р. до 3,4 у 2020 р. Певну тривогу викликає зростання середнього періоду погашення дебіторської заборгованості з 84 днів у 2018 році до майже 107 днів у 2020 році. Очевидно, компанії слід звернути увагу на фінансову надійність покупців та клієнтів. Натомість, середній період погашення кредиторської заборгованості знизився, що означає покращення фінансової незалежності ТОВ “Каргілл ЕН". Варто також розглянути коефіцієнти платоспроможності або коефіціснти погашення боргу, оскільки вони залежать від частки власного капіталу та пасивів у структурі капіталу компанії. Чим більша частка власного капіталу, тим фінансово стабільнішою $є$ компанія. Аналізуючи значення показників наведених в таблиці 5, доходимо висновку, що фінансова незалежність компанії ТОВ “Каргілл ЕН" покращилась, оскільки співвідношення усіх зобов'язань до підсумку балансу знизилось з 0,84 у 2018 році до 0,59 у 2020 році. Це означає, що сукупні борги компанії становили 59 \% iii сукупних пасивів у 2020 році.

\section{Таблиця 5}

Показники платоспроможності ТОВ “Каргілл ЕН”

\begin{tabular}{lccc}
\hline \multicolumn{1}{c}{ Показники платоспроможності } & 2018 p. & 2019 p. & 2020 p. \\
\hline Зобов'язання / Підсумок балансу & 0,84 & 0,62 & 0,59 \\
Зобов'язання / Власний капітал & 5,23 & 1,66 & 1,44 \\
Підсумок балансу / Власний капітал & 6,23 & 2,66 & 2,44 \\
\hline
\end{tabular}

Джсерело: розраховано автором за матеріалами офіційних даних звітності ТОВ “Каргілл Енімал Нутрішн” (Finansova zvitnist "TOV "KARHILL EN", 2021)

\section{Таблиця 6}

Розрахунок Z-рахунку Альтмана для ТОВ “Каргілл ЕН”

\begin{tabular}{|c|c|c|c|}
\hline & 2018 p. & 2019 p. & 2020 p. \\
\hline $\mathrm{Y}_{1}$ - Відношення оборотних коштів до загальних активів & $-0,05$ & 0,14 & 0,23 \\
\hline Ү2 - відношення нерозподіленого прибутку до загального обсягу активів & 0,06 & 0,21 & 0,16 \\
\hline Үз - відношення прибутку до сплати відсотків та податків до загальних активів & 0,15 & 0,34 & 0,22 \\
\hline Ү4 - відношення ринкової вартості власного капіталу до загальних зобов'язань & 0,19 & 0,60 & 0,70 \\
\hline Ү5 - відношення продажів компанії до її сукупних активів & 1,87 & 2,10 & 1,65 \\
\hline Altman's Z-score & 2,50 & 4,02 & 3,30 \\
\hline
\end{tabular}

Джерело: розраховано автором за матеріалами офіційних даних звітності ТОВ “Каргілл Енімал Нутрішн” (Finansova zvitnist "TOV "KARHILL EN", 2021) 
Подібну динаміку продемонструвало співвідношення зобов'язань компанії до іiі власного капіталу, знизившись 35,2 у 2018 році до 1,4 у 2020 році. Незважаючи на покращення платоспроможності компанії впродовж аналізованого періоду, варто зазначити, що зобов’язання ТОВ “Каргілл ЕН” все ще перевищують власний капітал.

Крім того, економісти обчислюють Z-рахунок Альтмана, щоб виміряти ймовірність банкрутства компанії i врахувати iii платоспроможність протягом певного періоду часу. Альтман розробив модель оцінки компанії на основі різних фінансових показників і спосіб застосування цього рахунку для оцінки ризику банкрутства компанії. Для виведення моделі Альтман використав дані багатьох фінансово незалежних та збанкрутілих публічних компаній разом із статистичною методологією під назвою аналіз множинної дискримінації. Повний Z-рахунок Альтмана включає 22 коефіцієнта, але його спрощений Z-рахунок включає лише п'ять найважливіших коефіцієнтів. Альтман запропонував використати наступні коефіцієнти для оцінки ймовірності банкрутства компаній.

$$
Z=1,2 Y_{1}+1,4 Y_{2}+3,3 Y_{3}+0,6 Y_{4}+0,99 Y_{5}
$$

де, $Y_{l}$ - відношення оборотних коштів до загальних активів;

$Y_{2}$ - відношення нерозподіленого прибутку до загального обсягу активів;

$Y_{3}$ - відношення прибутку до сплати відсотків та податків до загальних активів;

$Y_{4}$ - відношення ринкової вартості власного капіталу до загальних зобов'язань

$Y_{5}$ - відношення продажів компанії до іï сукупних активів.

Отже, згідно з розрахованим Z-рахунком Альтмана, ризик банкрутства ТОВ “Каргілл ЕН” знизився протягом двох розглянутих фінансових років, оскільки Zрахунок компанії зріс 3 2,5 у 2018 році до 3,3 у 2020 році. Важливо підкреслити, що Z-рахунок нижче 1,8 вказує на високий ризик банкрутства компанії, тоді як оцінка вище 3,0 означає, що ймовірність компанії збанкрутувати дуже низька.

\section{Висновки}

За результатами дослідження можна зробити висновок про покращення фінансового стану компанії ТОВ “Каргілл ЕН”. Зокрема, рентабельність власного капіталу компанії зросла з 37 \% у 2018 році до 54,4 \% у 2019 році, але знизилася до 40,2 \% у 2020 році. Водночас, рентабельність продажу ТОВ “Каргілл ЕН” також покращилась з 3,1 \% у 2018 році до $10 \%$ у 2020 році. Зростання чистого оборотного капіталу компанії $3-18,2$ млн. грн. у 2018 році до 117 млн. грн. у 2020 році, а також зростання коефіцієнтів загальної та швидкої ліквідності також підтверджують висновок щодо покращення фінансового стану компанії. Певну тривогу викликає зростання середнього періоду погашення дебіторської заборгованості з 84 днів у 2018 році до майже 107 днів у 2020 році. Загалом, фінансовий стан компанії покращився минулого року порівняно з 2018 роком, хоча і відбулось певне погіршення у порівнянні з 2019 роком. Відповідно до значення показника Zрахунку Альтмана, ймовірність банкрутства фірми $\epsilon$ дуже низькою.

Перспективи подальших досліджень. Важливим напрямом досліджень аналізу фінансового стану підприємств АПК, на наш погляд, повинно стати, оцінка узагальненого показника нестабільності компанії 3 врахуванням особливостей агропромислового комплексу України.

\section{References}

Bazilinska, O. Ya. (2009). Finansovyi analiz: teoriia ta praktyka: navchalnyi posibnyk. Kyiv: Tsentr uchbovoi literatury (in Ukrainian).

Breus, S. V., \& Shmatukha, V. S. (2016). Otsinka finansovoho stanu pidpryiemstva ta osnovni napriamy yoho pokrashchennia. Mizhnarodnyi naukovyi zhurnal "Internauka", 12(2), 35-37. URL: http://nbuv.gov.ua/UJRN/mnj_2016_12\%282\%29_9 (in Ukrainian).

Finansova zvitnist "TOV "KARHILL EN" (2021). URL: https:/e-data.com.ua/uo/finreport/367387/ (data zvernennia: 12.09.2021) (in Ukrainian).

Krasnikova, O. M., \& Mikhalets, A. I. (2020). Analiz finansovoho stanu ta yoho rol $\mathrm{v}$ upravlinni pidpryiemstvom. Naukovo-vyrobnychyi zhurnal "Biznes-navihator", 3(59), 131-134. doi: 10.32847/ business-navigator.59-22 (in Ukrainian)

Sosnovska, O. O. (2019). Metodychni pidkhody do diahnostuvannia finansovoho stanu pidpryiemstva. Modern Economics, 14, 264-271. doi: 10.31521/ modecon.V14(2019)-41 (in Ukrainian).

Tkachuk, H. O., Rybalko, S. V., \& Skliar, L. B. (2020). Metodychnyi pidkhid do otsinky stanu finansovoi systemy pidpryiemstva $\mathrm{v}$ umovakh zabezpechennia yoho ekonomichnoi bezpeky. Ukrainskyi zhurnal prykladnoi ekonomiky, 5(1), 288-296. doi: 10.36887/ 2415-8453-2020-1-34 (in Ukrainian).

Valiukh, A. V., \& Zaitsev, O. V. (2019). Analiz ta napriamy polipshennia finansovoho stanu pidpryiemstv Ukrainy. Infrastruktura rynku, 28, 255262. URL: http://www.market-infr.od.ua/journals/ 2019/28_2019_ukr/40.pdf (in Ukrainian). 